\title{
Grzegorz Trębicki
}

Uniwersytet Jana Kochanowskiego, Kielce

\section{Codifying chaos}

DOI: $10.19195 / 0867-7441.23 .21$

Review: Gary K. Wolfe, Critical Terms for Science Fiction and Fantasy. A Glossary and Guide to Scholarship, Greenwood Press, New York-Westport-London 1986, XXXVI, 162 pp.

Słowa kluczowe: fantasy, teoria literatury, literatura angielska i amerykańska, science fiction, krytyka literacka

Keywords: fantasy, theory of literature, science fiction, American and British Literature, literary criticism

The terminological and methodical chaos shrouding the whole field of "fantastic"1 or non-mimetic literature criticism has been frequently commented on by several researchers. ${ }^{2}$ This state of affairs has been probably unavoidable from the very start due to researchers and critics' diverse interests, worldviews and methodologies. One might argue, however, that while any attempts aimed at ordering this theoretical chaos or reaching some kind of consensus are bound to fail, it might be worthwhile at least to codify and briefly describe in one place what the contemporary criticism has to offer.

Published in 1986 the work of American academic critic of literature, Gary K. Wolfe $^{3}$ entitled simply Critical Terms for Science Fiction and Fantasy might be reasonably viewed as such an attempt. ${ }^{4}$ As the author states himself in the introduction:

1 I use the word "fantastic" literature as a popular label (rather than a strictly theoretical term) denoting all literature that can be juxtaposed with the traditional notion of "realistic" (or mimetic literature).

2 See for example: M. Oziewicz, One Earth, One People. The Mythopoeic Fantasy Series of Ursula K. Le Guin, Lloyd Alexander, Madelaine L'Engle and Orson Scott Card, North Carolina-London 2008, chapter one; Introduction to The Encyclopedia of Fantasy, ed. J. Clute, J. Grant, New York 1999; G. Trębicki, Worlds so Strange and Diverse. Towards a Genological Taxonomy of Non-mimetic Literature, Newcastle-Upon-Tyne 2015, chapters one and two; B. Attebery, Strategies of Fantasy, Bloomington-Indianapolis 1992, chapter one.

3 Gary K. Wolfe, Professor of Humanities in Roosevelt University's Evelyn T. Stone College of Professional Studies, has been a prominent figure in the world of SF and fantasy criticism since 1970s. His major works include also: The Known and the Unknown. The Iconography of Science Fiction, Kent 1979 and Evaporating Genres. Essays on Fantastic Literature, Middletown 2011.

4 Scholar David Sandner praised it as a „landmark” work and ,an indispensable guide to the sometimes peculiar terminology that has developed both in critical discourse and in popular discussions of fantasy and science fiction" (D. Sandner, Fantastic Literature: A Critical Reader, Westport 2004; quoted after "Gary K. Wolfe", [entry in:], Wikipedia, https://en.wikipedia.org/wiki/

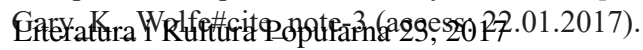

(C) for this edition by CNS 
For perhaps a century now, those who write and read (and write about) science fiction have been chronically unable to agree upon even the meaning of the term "science fiction" itself. In more recent years, similar debates have arisen regarding allied genres of fantastic literature, such as fantasy or horror fiction. Such confusion over the most basic terminology is only the most visible symptom of a growing problem [...]: On the one hand, concepts from traditional literary discourse often seem inadequate to describe the peculiar techniques and effects of the fantastic, while, on the other, terms coined specifically to describe such literature frequently appear eccentric or esoteric. Few branches of modern literary study have yielded as many neologisms, specialized definitions, attempts at identifying subgenres [...] This glossary - the first literary glossary devoted specifically to the study of fantastic literature - is not an attempt to prescribe such a vocabulary, but rather to provide a guide to the breadth and variety of the critical thought that has been brought to bear on this field. ${ }^{5}$

The glossary proper is preceded by a relatively short but quite informative introduction - Fantastic Literature and Literary Discourse, reflecting on the reasons of the terminological confusion mentioned above, and outlining the history of the criticism of the literature of the fantastic. It briefly reviews essential studies, to a smaller or larger extent related to the field, starting from Samuel Taylor Coleridge's Biografia Literaria and ending with notable works published in the second half of the 20th century. The key academic journals, specializing in fantastic literature, as well as most essential reference works are also mentioned.

The glossary itself comprises 140 pages of entries on a wide range of subjects related to broadly understood literary life ("fandom", "fanzin" or "blurb"), history of fantastic literature, literary trends and organizations ("Socialist Realism", "New Wave", "Inklings" or "Science Fiction Writers of America"), popular motifs found in fantastic fiction ("quest", "island utopia" or "laws of robotics"), and, obviously, literary theory. Here both more general terms, often pertaining to literature in general, if found relevant by the author, as well as to other sciences or fields of human activity, such as, for example, psychology or sociology, ("collective unconscious", "absurd", "surrealism", "post-structuralism", "metafiction" or "utopia") and more specialist ones ("world zero", "sword and sorcery", "soft science fiction", "sub-creation", "high fantasy" or "alternate world") have been included. Some of the entries on vital subjects have been, in fact, developed into short critical essays. This is, for example, the case of the definitions of the essential genres of non-mimetic literature such as "fantasy" and "science fiction". In the latter case Wolfe provides a short anthology of no fewer than 33 existing definitions of SF, ordered chronologically from Hugo Gernsback's brief description (1926) to more scholarly proposal of Northrop Fry, Sheridan Baker, and George Perkins (1985). He also briefly discusses the potential ways of defining SF and categorizes particular definitions. A similar procedure is repeated when it comes to other confusing or ambivalent terms. What is also noteworthy, although Wolfe's research is limited only to English language sources, occasionally he also mentions less known or popularized proposals. ${ }^{6}$

5 G.K. Wolfe, op. cit., p. VII.

6 For example, in his anthology of the definitions of fantasy he mentions the proposal by the Polish theorist Andrzej Zgorzelski; unfortunately at the same time he misquotes it, confusing

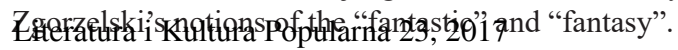

(C) for this edition by CNS 
Generally speaking, the author documents his sources well, albeit minor mistakes happen sporadically ${ }^{7}$ — which is, perhaps, unavoidable, taking into account the range of the work. The Glossary is also accompanied by an extremely useful bibliography of critical works on fantastic literature up to the year 1985 .

The study is impressive both in its ambitions and their execution and its two major shortages are rather predictable. First, it is limited, as it has already been remarked, to English language sources, thus ignoring a lot of interesting ideas that had the bad luck of being conceived in other parts of the world. Second, as the book has been published thirty one years ago, it does not include current developments (such as, by way of example, more recent theories and terms proposed by Farah Mendlesohn ${ }^{8}$ and Brian Attebery ${ }^{9}$ which have already proved quite influential). It is, perhaps, a pity, that Wolfe has not decided to revise and update his work.

Despite these minor — and as it has been suggested — understandable deficiencies, Wolfe's glossary remains an essential position of SF and fantasy criticism and is highly recommended to all scholars and readers confused by the sometimes esoteric and exotic terminology applied in the field.

7 Zgorzelski's proposal mentioned in the previous footnote was presented to English speaking public in SF Studies in 1979 and not in 1967 as the entry on "fantasy" suggests.

8 F. Mendlesohn, Rhetorics of Fantasy, Middletown 2008.

9 B. Attebery, Strategies of Fantasy, Bloomington-Indianapolis 1992.

\section{Stanisław Krawczyk}

Uniwersytet Warszawski

\section{What is science fiction for?}

DOI: $10.19195 / 0867-7441.23 .22$

Review: Brian Stableford, The Sociology of Science Fiction, Borgo Press, San Bernardino 1987, 192 pp.

Słowa kluczowe: komunikacja literacka, socjologia fantastyki, socjologia literatury

Keywords: literary communication, science fiction studies, sociology of literature

Sociological interest in science fiction is twofold. ${ }^{1}$ First, researchers look into the fictional depictions of social life. Second, they look into the social context of

1 Numerous examples of both approaches can be found in Arthur Evans' "Histories", [in:] The Oxford Handbook of Science Fiction, ed. R. Latham, New York 2014, p. 49. A useful overview of science-fictional speculations on society has been provided by Brian Stableford in his "Sociology",

Literatura i Kultura Popularna 23, 2017

(C) for this edition by CNS 